\title{
KENNIS EN HOUDING VAN VERPLEEGSTUDENTE AANGAANDE VIGS IN DRIE OPLEIDINGSINSTANSIES IN DIE, WES-KAAP
}

\author{
ME Bester en Y Arendse
}

\section{ABSTRACT}

A survey was done by means of a questionnaire to obtain information on the knowledge and attitudes of 297 nursing students from three training institutions in the Western Cape regarding HIV-infection and AIDS-patients.

Results indicated:

- The average knowledge regarding AIDS scored 72,5\%

- They generally had a positive attitude regarding the caring for AIDS-patients;

- $81 \%$ of the junior and $54 \%$ of the senior students were of opinion that their training were inadequate while

- $91,5 \%$ of the respondents held the opinion that the training hospital must provide more training.

It is recommended that the curricula of training institutions make adequate provision for relevant training regarding AIDS.

\section{OPSOMMING}

'n Opname is met behulp van ' $n$ vraelys onder 297 verpleegstudente verbonde aan drie opleidingsinstansies in die Wes-Kaap gedoen. Die doel van die studie was om te bepaal of verpleegstudent se feite like kennis ten opsigte van HIV-infeksie en VIGS korrek is, asook hulle houding teenoor VIGS. pasiënte.

\section{Die resultate toon dat:}

- Verpleegstudente se kennis van VIGS gemiddeld 72,5\%;

- Hulle 'n positiewe ingesteldheid teenoor die vesorging van pasiënte met VIGS het, maar dat

- $81 \%$ van die junior en $54 \%$ van die senior studente van mening is dat hulle opleiding onvoldoende is, tenwyl

- 91,5\% van die respondente van mening was dat die opleidingshospitaal meer opleiding moet verskaf.

Die aanbeveling word gemaak dat die kurrikulums van opleidingsinstansies voldoende voorsiening moet maak vir toepaslike opleiding rondom VIGS.

\section{INLEIDING}

In 1981 het die wêteld die eerste keer bewus geword van Verworwe Immuun Gebreksiekte (VIGS) toe ongewone gevalle van pneumonie in Los Angeles, Amerika gerapporteer is. Ses jaar later in 1987 is VIGS as 'n pandemie verklaar (Goddard,1988).

In 1982 is die eerste twee VIGS-pasiënte in Suid-Afrika gediagnoseer en in 1988 was daar 76 pasiënte. Cremers (1993) het reeds in 1993 geraam dat $30 \%$ van Suid-Afrika se seksuele aktiewe persone in 1994 "Human Immuun Virus" (HIV)-positief sou wees.

Gesien in die lig van die toename in die insidensie van HIV-positiewe gevalle wêreldwyd asook in Suid-Afrika, het dit onvermydelik geword dat verpleegstudente toenemend in kontak sal kom met pasiënte wat HIV-positief is of VIGS het.

Kerr \& Horrock (1990) het gevind dat daar 'n groot behoefte bestaan vir opleiding oor VIGS om die houding en kennis van studentverpleegkundiges te beinvloed. In 'n studie van Lester \& Beard (1988) het $96,6 \%$ $(\mathrm{N}=177)$ van studentverpleegkundiges aangedui dat VIGS-pasiěnte dieselfde verpleegsorg behoort te ontvang as enige ander pasiënt. Van dié 177 studentverpleegkundiges, het bykans die helfte (49\%) egter aangedui dat hulle nie bereid is om VIGS-pasiënte te verpleeg nie en $17,5 \%$ van die respondente het aangedui dat hulle eerder sal bedank as om VIGS-pasiënte te verpleeg.

Chittey (1989) rapporteer resultate van 'n opname wat in Tenesee, Amerika gedoen is om te bepaal hoe verpleegstudente se kurrikulums aangepas is om verpleegstudente voor te berei om die pasiënte te verpleeg. Daar is gevind dat daar sommige instellings is wat op daardie stadium nog glad nie die kurrikulums aangepas het nie.

Sher (1988) beweer dat daar nog steeds baie misverstande bestaan oor VIGS Verpleegkundiges is net so onkundig oor VIGS en vrees vir die onbekende aangaande VIGS. Die angs en vrese van verpleegkundiges kan verlig word deur feitelike kennis aan haar te verskaf.

Die Suid-Afrikaanse Verpleegstersvereniging het 'n standpuntmemorandum rondom VIGS geformuleer. Dit spesifiseer dat:

- Geen verpleegkundige om etiese redes sal weier om 'n pasiënt wat aan VIGS lei, te verpleeg nie;

- Verpleegonderwysers die verantwoordelikheid het om seker te maak dat die studentverpleegkundiges bekend is met die verpleegsorgvaardighede wat selfkontaminasie en kruisinfeksie van die siekte sal voorkom en dat

- Die student in staat moet wees om haar eiesoortige verpleegvaardighede by die spesifieke verpleegbehoeftes van die VIGS-pasiënt, aan te pas.

Dit blyk uit bogenoemde dat die verpleegkundige in die toekoms toenemend gekonfronteer sal word om VIGS-pasiënte te verpleeg. Tot watter mate sy daarin gaan slaag om 'n positiewe gevoel teenoor die pasiènt uit te dra en voorkom dat diskriminerende praktyke die verhouding tussen haar/hom en die pasiënt nadelig beïnvloed, gaan bepaal word deur die mate van feitelike kennis en ondersteuning wat sy as werker gaan ontvang (Christie \& Hickson, 1990). 


\section{PROBLEEMSTELLING}

Teen die agtergrond van bogenoemde beredenering, is die navorsing geloods om die volgende vrae aan te spreek:

- Beskik studentverpleegkundiges in die Wes-Kaap oor die nodige feitelike kennis ten opsigte van HIV en VIGS?

- Het die studentverpleegkundiges enige besware om HIV-positiewe pasiënte of VIGS-lyers te verpleeg?

- Is die studentverpleegkundiges van mening dat hulle voldoende voorberei word om HIV-positiewe en VIGS-pasiënte te verpleeg?

\section{METODOLOGIE}

'n Nie-eksperimentele, beskrywende navorsingsontwerp is geselekteer. Die steekproef van 297 studentverpleegkundiges het bestaan uit junior en senior verpleegstudente verbonde aan onderskeidelik twee universiteite en een verpleegkollege in die Wes-Kaap.

'n Vraelys is deur die navorsers opgestel gegrond op 'n deeglike studie van teoretiese en empiriese literatuur. Die vraelys is aan portuurgroepevaluering onderwerp om inhoudsgeldigheid te verseker. Slegs vrae waaroor daar 'n minimum van $80 \%$ konsensus bestaan het, is in die finale vraelys ingesluit. Die vraelyste is deur dosente van die opleidingsinstansies uitgedeel, onmiddellik voltooi en weer ingesamel. Sodoende is verseker dat verpleegstudente nie mekaar se response en dus die betroubaarheid van die resultate, kon beinvloed het nie. Die vraelyste is anoniem ingevul en die dosente het ook nie die response van die studente gesien nie.

Dichotomiese vrae is gestel ten opsigte van:

- Biografiese besonderhede (ouderdom, geslag, huwelikstaat, vlak van opleiding, geloof ens.)

- Kennisvlak van studente oor HIV en VIGS:

- Oorsake van VIGS

- Verskille tussen HIV en VIGS

- Oordrag/verspreiding van VIGS

- Algemene tekens en simptome

- Risiko's vir verpleegkundige

- Aanmelding van VIGS

- Opleiding ontvang

- Houding:

- Nie-professionele kontak met VIGS-persoon

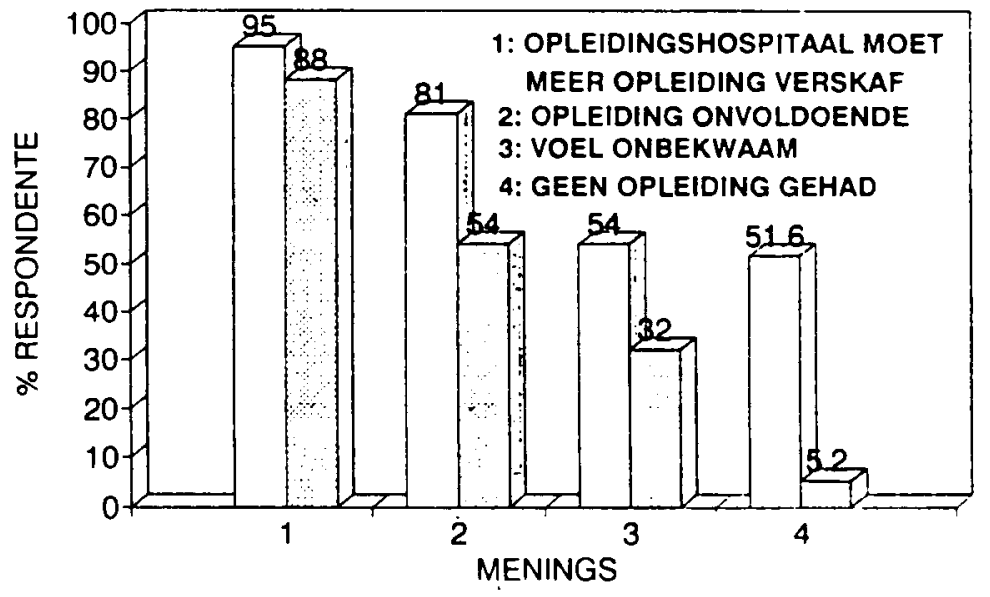

JUNIOR STUDENTE

SENIOR STUDENTE

Figuur 1: Studente se mening t.o.v. opleiding $\quad \mathrm{N}=297$

- Professionele kontak met VIGS. pasiënte

- Etiese kwessies rakende die versorging van VIGS-pasiënte.

\section{DATA-ANALISE}

Biografiese besonderhede:

Die profiel van die studentverpleegkundiges was as volg:

- 94\% van die respondente het aan die Christelike en $6 \%$ aan die Moslemgeloof behoort;

- $96 \%$ van die respondente was ongetroud;

- $96 \%$ van die respondente was vroulik;

- $61,3 \%$ van die respondente was junior (eerste- en tweedejaar) en $39,7 \%$ was senior (derde- en vierdejaar) studente
Geen noemenswaardige verskille kon bespeur word tussen die geloofsoortuiging, huwelikstatus of geslag van die respondente en hulle kennis of houding nie.

\section{Kennisvlak}

- Die gemiddelde kennisvlak van die studente soos gemeet in die aantal korrekte response op die kennisvrae, was $71 \%$ vir die junior studente en $74 \%$ vir die senior studente, wat nie 'n noemenswaardige verskil is nie.

- In Figuur 1 word die studente se mening ten opsigte van die opleiding wat hulle by die kollege/universiteit ontvang het asook die opleiding ontvang by die primêre opleidingshospitaal, weergegee. Uit hiérdie Figuur blyk dit duidelik dat studente ' $n$ behoefte het aan meer opleiding. Dit moet uitgelig word dat $51,6 \%$ van die junior studente en $5,2 \%$ van die senior studente, wel reeds

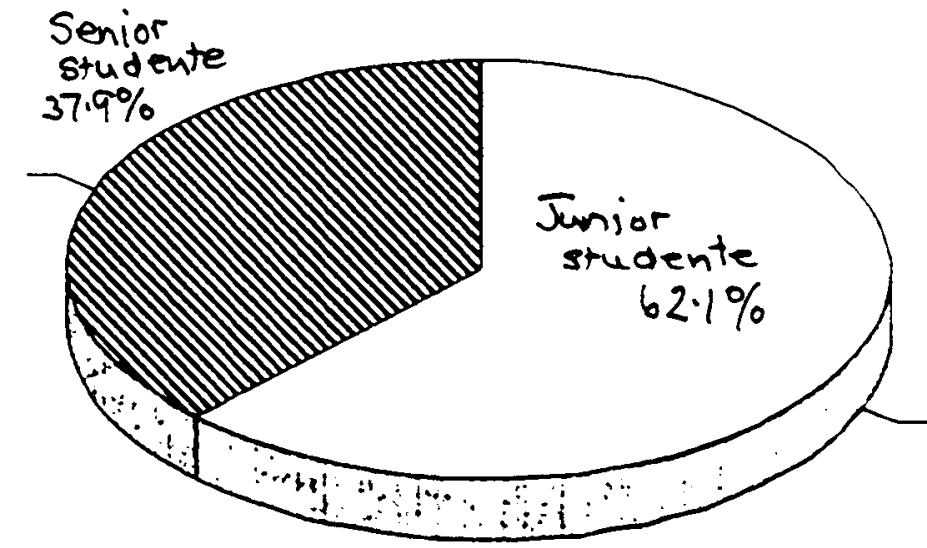

Figuur 2: Houding t.o.v. VGS: Het vriende met VGS $\quad \mathbf{N}=29$ 
VIGS-pasiënte verpleeg het, maar nog geen opleiding oor VIGS ontvang het nie.

\section{Houding}

- In geheel gesien, het $71 \%$ van die junior studente en $74 \%$ van die senior studente 'n positiewe houding weerspieël;

- $9,76 \%$ van die studente het aangedui dat hulle ' $n$ vriend ken wat VIGS het (onderskeidelik $9,8 \%$ van die junior en 9,5\% van die senior studentverpleegkundiges). In Figuur 2 word aangedui wat die studente wat wel 'n vriend met VIGS het, se respons was op die vraag of hulle sal weier om VIGS-pasiënte te verpleeg. Dit is insiggewend dat veral junior studente aangedui het dat hulle sal weier, wat moontlik kan wees omdat hulle kennis gebrekkig is en hulle onbekwaam voel.

- Op die vraag oor wat hulle sal doen indien hulle verplig sou word om 'n VIGS-pasiënt te verpleeg, het $2,8 \%$ van die junior en $0,8 \%$ van die senior studente aangedui dat hulle eerder sou bedank.

- $21,9 \%$ van die respondente het aangetoon dat hulle familie beswaar sou aanteken indien hulle met VIGS-pasiënte sou werk.

- 'n Interessante bevinding was dat diegene met 'n kennisvlak van meer as $75 \%$, meer negatief ingestel was teenoor die VIGS-pasiënt as diegene wat 'n kennisvlak van minder as $75 \%$ gehad het. Hiérdie bevinding het vir beide die junior en die senior studente gegeld. Dit is egter nie binne die omvang van die navorsing moontlik om te bespiegel oor die rede vir dié bevinding nie.

\section{GEVOLGTREKKINGS}

$\mathrm{Na}$ aanleiding van die data-analise, word die volgende gevolgtrekkings gemaak:

- Die algemene kennisvlak van junior en senior studentverpleegkundiges soos getoets in hiérdie navorsing, is bevredigend. Studente self beskou hulle egter as onvoorbereid en onbekwaam en is van mening dat meer opleiding gegee behoort te word.

- Studentverpleegkundiges het 'n positiewe houding aangedui. Daar was egter onsekerhede wat moontlik toegeskryf kan word aan onkunde en gevolglike onsekerheid.

\section{AANBEVELINGS}

- VIGS behoort reeds vanaf die eerste studiejaar en voor die eerste blootstelling aan die kliniese praktyk as deel van die kurrikulum ingebou word.

- 'n Analise van die kurrikulums in terme van die tipe, hoeveelheid en frekwensie van opleiding ten opsigte van VIGS, behoor gemaak te word.

- Standaarde moet gestel word ten opsigte van die aard en omvang van onderrig in sake VIGS.

- Studente moet die geleentheid kry om oor die etiese implikasies te besin.

- Sielkundige ondersteuningsdienste behoort beskikbaar te wees binne die kliniese opleidingsfasiliteit vir studentverpleegkundiges.
- Studentverpleegkundiges moet ook indiensopleiding ondergaan in die kliniese fasiliteite waar hulle opleiding kry. Waar indiensopleidingsgeleenthede reeds vir opgeleide personeel bestaan, behoort studentverpleegkundiges oook daarby ingeskakel te word.

\section{VERWYSINGS}

Chitty KK. (1993): A National survey of Aids education in School of Nursing. Journal of Nursing Education, 28(4):150-155.

Cremers P.(1993): Aids and the Health Care Worker. Nursing RSA, 8(1):37-39.

Goddard J. (1989): A current overview of AIDS and its impact on Society. Nursing RSA, $4(2): 17-20$.

Kerr CI, Horrocks MJ. (1990): Knowledge, Values, Attitudes and Behavioural Intent of Nova Scotia Nurses towards AIDS and Patients with AIDS. Canadian Journal of Public Health. 81(3):125-128.

Lester LB, Beard BJ. (1988): Nursing Students' attitudes towards AIDS. Joumal of Nursing Education, 27(9):399-403.

VIGS: (1988): Standpuntmemorandum van die SAVV. Verpleging RSA, 3(3):12.

M.E. Bester
D.Cur.Universiteit van Stellenbosch
Senior Lektor: Universiteit van
Stellenbosch
Y. Arendse
Hons.B. Verpleegkunde
(Verplegingsonderwys) Universiteit van
Stellenbosch
Senior Geregistreerde
Verpleegkundige: Primêre
Gesondheidsorgdienste, Strand.

